\title{
PRELIMINARY BACK-ANALYSIS OF THE HEIGHT OF MUD BRICK FORTIFICATIONS BASED ON GEOARCHAEOLOGICAL DATA AT TELL EL-RETABA SITE IN EGYPT
}

\author{
Jerzy Trzciński ${ }^{1 *}$, Małgorzata Zaremba ${ }^{2}$, Slawomir Rzepka ${ }^{3}$, Witold Bogusz ${ }^{4}$, \\ Tomasz Godlewski ${ }^{4}$, Tomasz Szczepański ${ }^{5}$ \\ ${ }^{1}$ Wrocław Research Centre EIT+, Stabłowicka 147, 54-066 Wrocław, Poland; e-mail: jerzy.trzcinski59@gmail.com \\ ${ }^{2}$ Institute of Archaeology, Cardinal Stefan Wyszyński University, Wóycickiego 1/3, 01-938 Warsaw, Poland \\ ${ }^{3}$ Institute of Archaeology, University of Warsaw, Krakowskie Przedmieście 26/28, 00-927 Warsaw, Poland \\ ${ }^{4}$ Building Structures and Geotechnics Department, Building Research Institute, Ksawerów 21, 02-656 Warsaw, Poland \\ ${ }^{5}$ Institute of Hydrogeology and Engineering Geology, Faculty of Geology, University of Warsaw, Żwirki $i$ Wigury 93, \\ 02-089 Warsaw, Poland \\ * corresponding author
}

\begin{abstract}
The Tell el-Retaba archaeological site is located at Wadi Tumilat, a shallow valley running from the Nile Delta to the Bitter Lakes. In ancient times, a route connecting Egypt with Syria-Palestine ran across the site. In the $13^{\text {th }}$ century BC, during the rule of Ramesses II, a fortress surrounded by "Wall 1" was erected and in times of Ramesses III in the $12^{\text {th }}$ century BC, a larger fortress surrounded by "Wall 2" and "Wall 3" was constructed. Using the finite element method (FEM) and ZSoil 2D\&3D software, the wall heights were modelled and their soil-structure interaction was analysed. Strength of the wall depended on size and strength of bricks and mortar, brickwork, wall shape and foundation. Ancient builders using mud bricks must have known from practical experience the essentials of a wall construction, in which the height to width ratio was at 1.75 to 1.85 . Moreover, they must have related the engineering properties of the material with the height of the construction and its purpose. The width to height ratio must have been used and related by ancient Egyptians to the ground resistance. Modelling has shown that, at wall width of $5 \mathrm{~m}$, the foundation would have lost its stability at wall height of 13-14 $\mathrm{m}$ and bricks from the lower part of the wall would be destroyed. According to the undertaken assumptions, in order to retain stability, the wall height must have been limited to about 8-9 m.
\end{abstract}

Key words: fortress walls, engineering properties of mud bricks, finite element method (FEM), fortification size

Manuscript received 20 April 2017, accepted 17 November 2017

\section{INTRODUCTION}

Tell el-Retaba is an archaeological site in north-eastern Egypt, about $35 \mathrm{~km}$ to the west of Ismailia, in the middle of a shallow valley of Wadi Tumilat running from the Nile Delta to the Bitter Lakes, along which the Suez Canal was built. In ancient times, the valley was one of the arteries between Egypt and Syria-Palestine, and Tell el-Retaba was a strategic location, with strong fortifications established during certain periods. The detailed position of the site was recently described by Trzciński et al. (2016).

In the Second Intermediate Period $\left(18^{\text {th }}-16^{\text {th }}\right.$ century BC), the first settlers - the Hyksos from Syria-Palestine - appeared in the area. With the beginning of the New
Kingdom $\left(16^{\text {th }}\right.$ century BC), an Egyptian settlement was established on the site. In the $13^{\text {th }}$ century $\mathrm{BC}$, during the reign of Ramesses II, a fortress surrounded by "Wall 1" was established. During the reign of Ramesses III in the first half of the $12^{\text {th }}$ century BC, a new, larger fortress was constructed and surrounded by a much more massive "Wall 2" and additionally, without clear reasons, the "Wall 3" with a migdol type massive protective gateway (Fig. 1, Table 1).

Activities of the Polish-Slovak Archaeological Mission that began in 2007 (Rzepka et al., 2009, 2011, 2014, 2015) in the Tell el-Retaba archaeological site resulted in uncovering of the ruins of numerous different constructions. They originated from different periods (from the Second Intermediate Period to the Third Intermediate Period, i.e. 


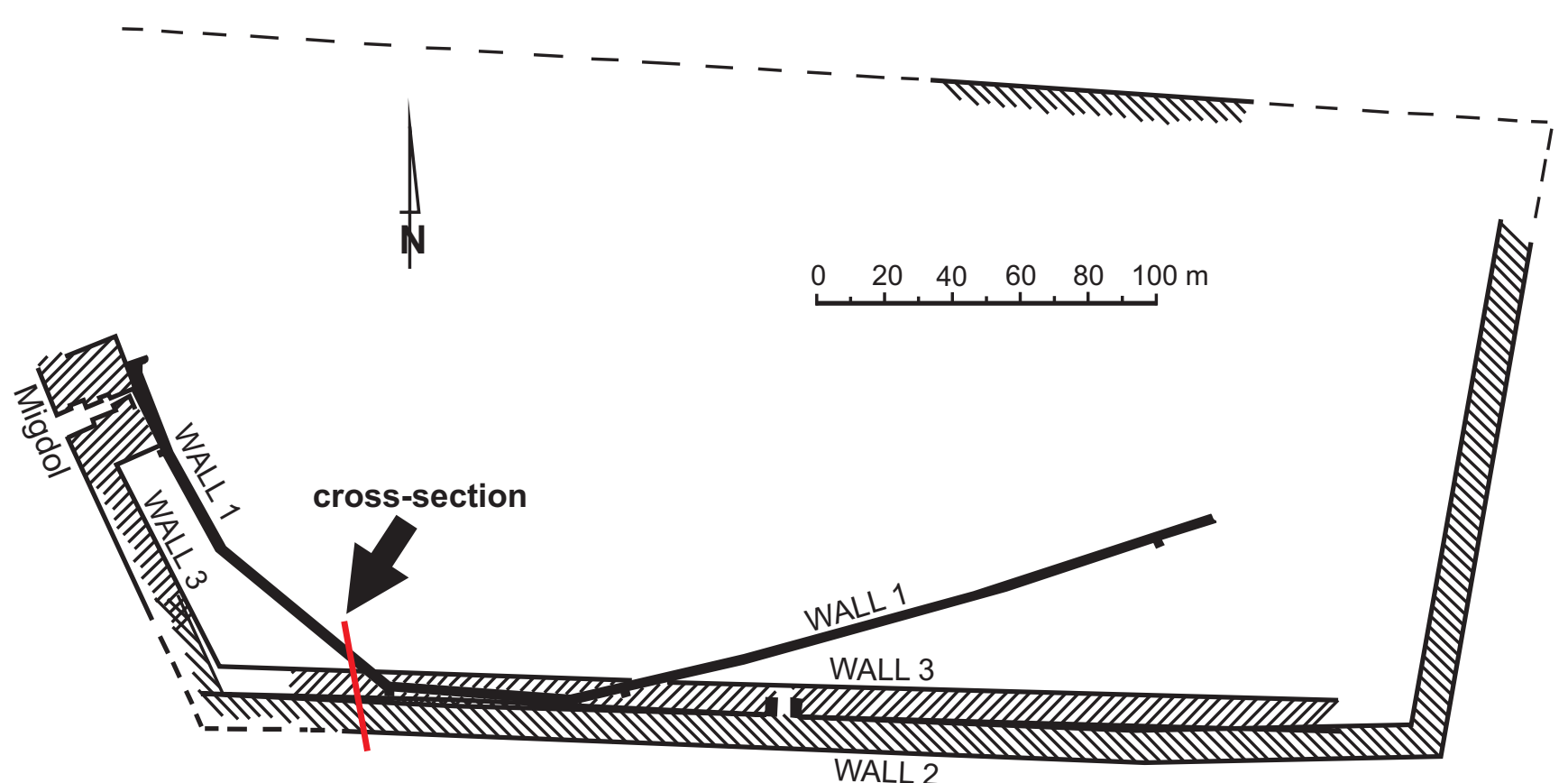

Fig. 1. Plan of the tell, with location of the cross-section through "Walls 1", "Wall 2" and "Wall 3". Based on Petrie and Duncan (1906: pl. XXXV).

from the $18^{\text {th }}$ to the $7^{\text {th }}$ century $\mathrm{BC}$ ) and are the remains of buildings with diverse functions. They include: defence walls, housings, stables for animals, granaries, and burial chambers. Some of them originated as state investments, i.e. fortifications or barracks, and some as private enterprises, including small houses, extensions and small silos. All these miscellaneous constructions were made of sun-dried mud bricks, which is characteristic for the constructions of ancient Egypt. At that time, mud bricks were typically used as a construction material (Spencer, 1979; Kemp, 2000; Emery, 2011), whereas stone was used only for a construction of some temples and most important tombs (Arnold, 2001).

All structures in Tell el-Retaba were constructed of material commonly referred to as "mud brick". However, the material is highly variable. Mud bricks differ in size, colour, the material used for their production and engineering properties. One of the aims of the last season's site works in autumn 2015, conducted by the Polish-Slovak Archaeological Mission, was to investigate the geological-engineering properties of mud bricks used for the construction of various buildings. Laboratory tests were focused on obtaining selected engineering parameters of the bricks, including their strength. The obtained results have allowed assessing the maximal heights of the buildings, which at present are preserved in fragments only. The latter issue is particularly interesting in the case of the defence walls of the Tell el-Retaba fortresses.

\section{MUD BRICK FORTIFICATIONS IN TELL EL-RETABA}

Ruins of defence constructions, i.e. "Wall 1", "Wall2" and "Wall 3" and a migdol type gateway are preserved at the Tell el-Retaba site (Trzciński et al., 2016, Figs 2, 3).

History of settlement at the archaeological site at Tell el-Retaba, Egypt.

\begin{tabular}{|l|c|c|}
\hline \multicolumn{1}{|c|}{ Period } & Age & Way of usage \\
\hline Late Period & $7^{\text {th }}-4^{\text {th }}$ century BC & absence of architectural remains \\
\hline Third Intermediate Period & $11^{\text {th }}-7^{\text {th }}$ century BC & open settlement \\
\hline Beginning of $20^{\text {th }}$ Dynasty & 1 . half of $12^{\text {th }}$ century BC & $\begin{array}{c}\text { construction of new larger fortress with “Wall 2", followed by “Wall 3" } \\
\text { and migdol entrance gateway construction; 100 years of fortress usage }\end{array}$ \\
\hline $\begin{array}{l}\text { 1. half of } 19^{\text {th }} \text { Dynasty } \\
\text { beginning of } 13^{\text {th }} \text { century BC }\end{array}$ & $\begin{array}{c}\text { construction of fortress with "Wall 1" (core and enlargement); } \\
\text { several decades of fortress usage }\end{array}$ \\
\hline 2. half of $18^{\text {th }}$ Dynasty & $14^{\text {th }}$ century BC & settlement hiatus for 100 years \\
\hline 1. half of $18^{\text {th }}$ Dynasty & $16^{\text {th }}-15^{\text {th }}$ century BC & Egyptian settlement \\
\hline Second Intermediate Period & $18^{\text {th }}-16^{\text {th }}$ century BC & Hyksos settlement \\
\hline
\end{tabular}




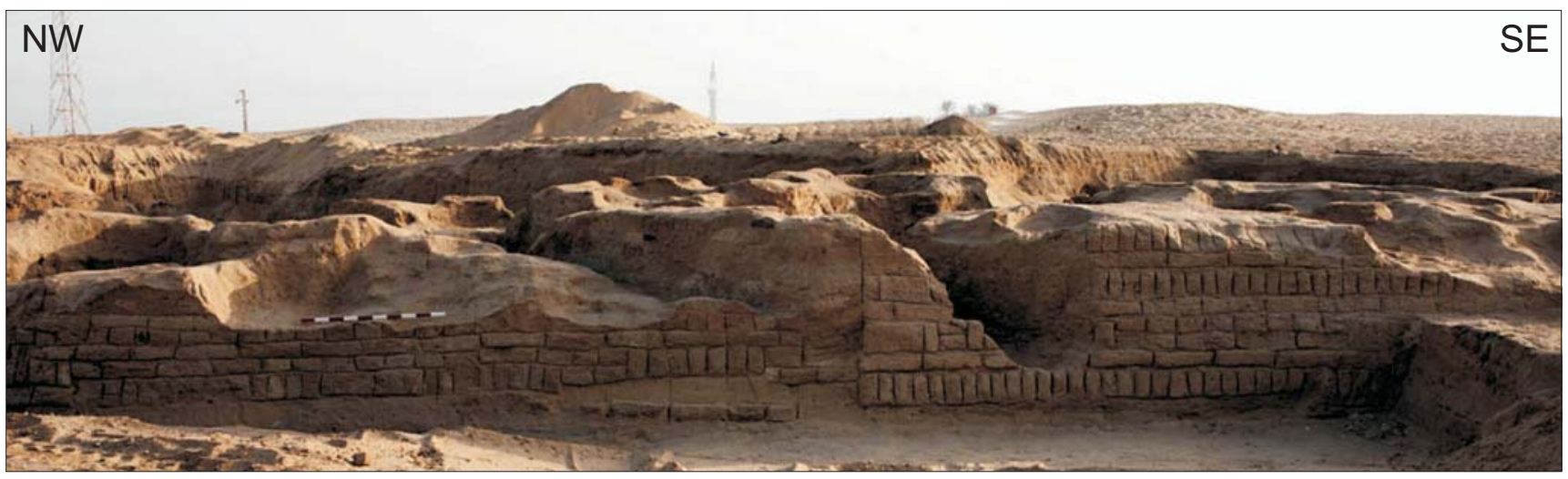

Fig. 2. Outer face of "Wall 1". Photo by S. Rzepka.

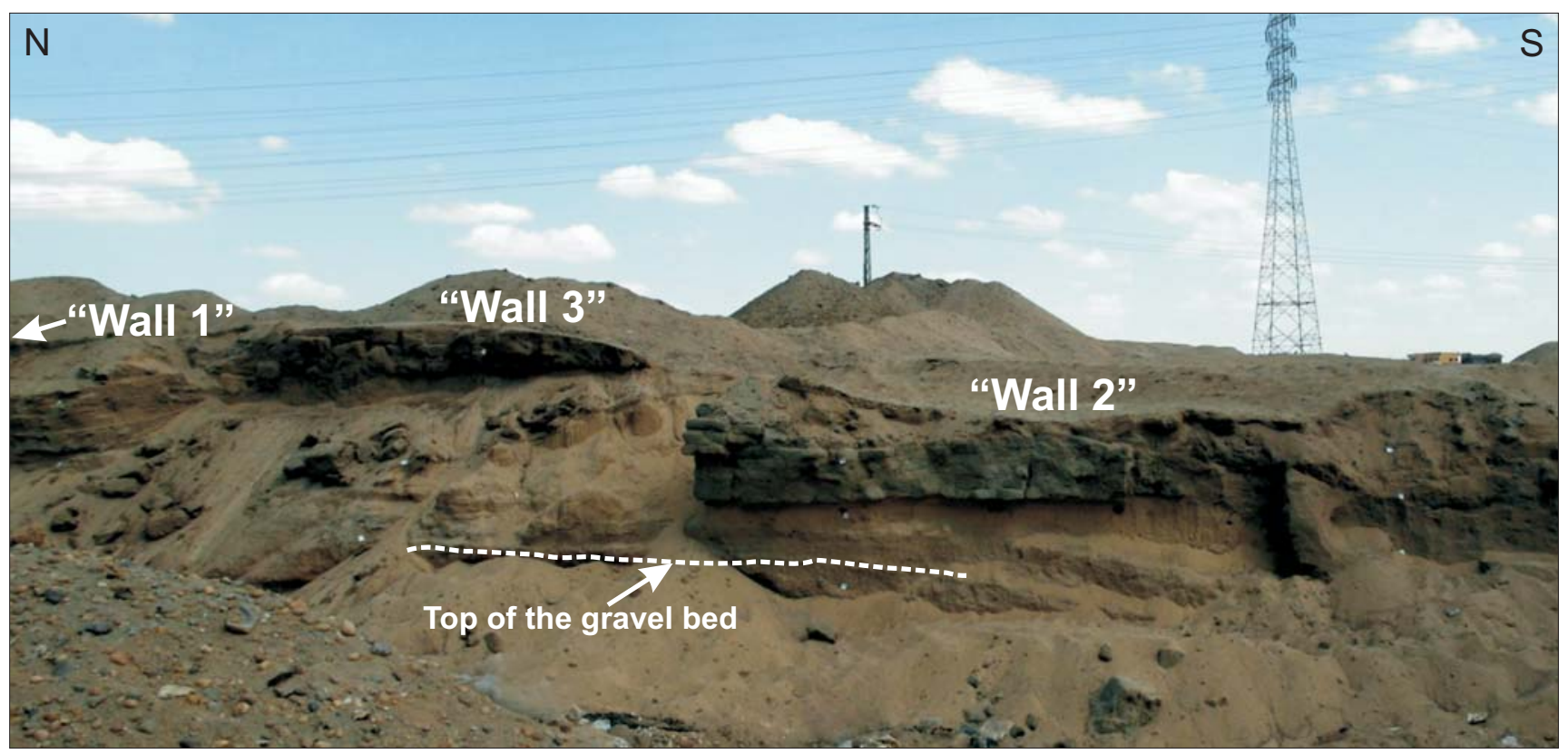

Fig. 3. Fragment of trench with transverse cross-section of "Wall 2" and "Wall 3". "Wall 1" occurs to the north of "Wall 3". Photo by S. Rzepka.

\section{"Wall 1" - fortifications from the $19^{\text {th }}$ Dynasty}

"Wall 1" represents the oldest defence walls, confirmed by archaeological investigations at Tell el-Retaba (Fig. 2). W.M.F. Petrie, who exposed southern and western part of these fortifications, considered them without any evidence to have been derived from the First Intermediate Period $\left(23^{\text {rd }}-21^{\text {st }}\right.$ century BC) and built by the Asiatics, who apparently came into Egypt in large numbers at that time (Petrie and Duncan, 1906: 28-29). The investigations of the Polish-Slovak Archaeological Mission have refuted this hypothesis and supplied a solid proof that the "Wall 1 " was built during the early $19^{\text {th }}$ Dynasty, i.e. in the $13^{\text {th }}$ century BC (Górka and Rzepka, 2011). The investigations have also indicated that the "Wall 1" was not a uniform construction. An older core, about $2 \mathrm{~m}$ thick, was distinguished within the wall, with thick extensions installed later on both sides of the wall, but also during the first half of the $19^{\text {th }}$ Dynasty. Finally, the "Wall 1" reached a width of over $5 \mathrm{~m}$.
Dating of the "Wall 1" is based on the analysis of ceramics, found in the archaeological layers beneath the wall and adjacent to it. Such method of dating is not very precise, but most probably the wall was constructed during the reign of Ramesses II, who evidently established a temple at Tell el-Retaba (Petrie and Duncan, 1906: 29, pl. XXIXXXXI). The Ramesses II fortress functioned for only several decades and became a ruin already at the end of the $19^{\text {th }}$ Dynasty (Table 1).

\section{"Wall 2" and "Wall 3" - fortifications from the $20^{\text {th }}$ Dynasty}

At the beginning of the $20^{\text {th }}$ Dynasty $\left(12^{\text {th }}\right.$ century $\mathrm{BC})$, the ruins of the Ramesses II fortress were levelled, and Ramesses III constructed on them a new, larger and massively fortified fortress. The "Wall 2" belonged to this fortress; it can be dated precisely because a foundation deposit with objects containing inscriptions of Ramesses III 
was discovered under its south-eastern corner (Petrie and Duncan, 1906: pl. XXXIIA, XXXIV). The "Wall 2" was about $9 \mathrm{~m}$ wide. Both its original height and the function of its massive construction are unknown. Soon after the "Wall 2" was constructed, the "Wall 3" was erected; this was a massive, approximately $8.5 \mathrm{~m}$ wide wall, partly founded on the "Wall 2" (Fig. 3). According to the archaeological data, this event took place probably still during the reign of Ramesses III. In the southern part of the site, where longer fragments of both walls were exposed by Petrie and the following excavations of Egyptian missions, the "Wall 2" was found to have been about $1.3 \mathrm{~m}$ high only at the time when the "Wall 3" was built upon it. This issue requires further studies (Rzepka et al., 2014: 74-75), but it is possible that the "Wall 2" did not have defensive functions but was rather a retaining wall of a man-made platform, on which Ramesses III built his fortress surrounded by the "Wall 3", with a massive midgol type gateway from the west.

\section{METHODOLOGY OF FIELD AND LABORATORY INVESTIGATIONS}

The analysis of lithological, physical and mechanical properties of mud bricks from the Tell el-Retaba site concentrated on the uncovered fragments of "Wall 1", "Wall 2" and "Wall 3", which were preserved in a trench in the western part of the site (Figs 1,3). Detailed documentation of the exposed wall fragments, including the ground on which they were built, was made during the field works. A detailed description of the applied methodology of field and laboratory analyses was given by Trzciński et al. (2016). The laboratory investigations were conducted according to PN-88/B-04481 and PKN-CEN ISO/TS 17892-7 standards.

\section{MODELLING OF THE HEIGHT OF THE DEFENCE WALLS AND THEIR INTERACTION WITH A GROUND}

The analysis was conducted for a fortification erected as a masonry construction. The walls were made of various moulding, usually bricks and blocks of diverse sizes, and assembled in layers. These elements mainly transferred compressive loads. Even distribution of load in a construction requires fulfilling the following rules:

- the elements should be bound, i.e. a joint in one layer should be overlain by an element of the next layer;

- for construction reasons, the most favourable arrangement of elements is as a flat layer, sometimes for decorative reasons - as a herringbone bond or in an upright position;

- wall layers should be laid horizontally.

Based on general rules of masonry structures (Sieczkowski and Nejman, 2002), wall capacity depends on several factors, such as:

- shape and size of wall elements (bricks and mortar),

- material strength of wall elements,
- type of brickwork,

- shape and type of wall and its support.

Additionally, in the case of freestanding wall structures, such as the defence walls at Tell el-Retaba, a significant influence on the stability of the entire construction have the foundation type and the geological-engineering properties of the ground.

\section{CALCULATION METHODS AND ASSUMPTIONS}

Numerical analysis was conducted with ZSoil 2D\&3D software, which uses the finite elements method (FEM). The method allows for a complex analysis of the construction and the ground on which it is built, and the mutual interactions between these elements. The ground and the construction are continuous objects, reproduced by a finite number of discrete elements. These elements are described by a finite number of material parameters; the physical model based on these parameters is translated into a numerical model with necessary simplifications (Truty et al., 2012). In each subsequent calculation step, the stress-strain relationship is analysed for each finite element, and an equilibrium state is searched for these elements. Results of calculations is a new stress and strain state obtained due to changes in the model, e.g. after applying additional load resulting from the assemblage of a next wall layer. The software allows for modelling of subsequent stages of wall erection and searching for conditions at which its destruction may take place due to various factors mentioned above and influencing the wall strength.

For calculations of the wall substratum, a linear-elastic perfectly plastic model with the Mohr-Coulomb (MC) failure criterion was used. The structural elements (mud bricks) were analysed using the Hoek-Brown (HB) model, which is used for rocks. This is an elastoplastic model with plasticity surface described by the Menetrey-Willam criterion (Truty et al., 2012). A mean value of strength in uniaxial compression for bricks, obtained in laboratory tests, and the tensile strength, which is $10 \%$ of the value of compression strength, were used in the calculations. Mortar between the mud bricks was modelled by the angle of shear resistance and cohesion. These parameters were calculated based on the uniaxial compression strength of mortars and tensile strength, which had been assumed as $10 \%$ of the value of compression strength. The thickness of mortar was not used directly in the calculations. In the calculations, the joints were included as contact type interface elements. These are virtual elements with regard to size or thickness, but with parameters of the mortar attributed to them.

The wall substratum includes sediments of the channel facies with prevalence of a gravel fraction (Trzciński et al., 2016). Such sediments usually occur beneath the walls at the Tell el-Retaba site. A density index of $\mathrm{I}_{\mathrm{D}}>0.70$ was assumed for these sediments, i.e. as for coarse sand with gravel in a densified state. Laboratory and in situ (sounding) investigations were not conducted for the analysed substratum sedi- 
ments at this stage of analysis; therefore, these assumptions were made based only on macroscopic analyses conducted during site works. Geotechnical parameters required for the constitutive model were established for the substratum based on a personal experience and the PN-81/B-03020 standard. The assumed conditions should be treated as careful estimations according to Eurocode 7 (PN-EN 1997-1:2008; PN-EN 1997-2:2008). Therefore, at this stage of investigations, the assumptions for the ground conditions should be considered as minimal. At present, the substratum on which the walls were founded, probably displayed an even higher density, resulting from later diagenetic processes. Parameters for the bricks, mortars and substratum, which were used in the calculations, are presented in Table 2 .

\section{RESULTS}

In the first stage of numerical analyses, the strength of wall elements in plain-strain conditions was analysed (2D model), taking into account the soil. Calculations were conducted for averaged wall parameters and assumed ground conditions as described above. A simplified model was applied assuming that the entire wall is built of uniform material, i.e. has parameters corresponding to the average value of brick strength in uniaxial compression. A wall width of $5 \mathrm{~m}$ was taken to the analyses and the entire analysed area was subdivided into a finite number of elements with mesh size of $10 \times 10 \mathrm{~cm}$. Based on modelling, the height of an uniform wall was reconstructed (Fig. 4). The maximum

Table 2

Brick and mortar parameters used in the calculations in the modelling of defence walls.

\begin{tabular}{|c|c|c|c|c|c|}
\hline \multicolumn{2}{|c|}{ Model } & \multicolumn{2}{c|}{ Hoek-Brown } & \multicolumn{2}{c|}{ Mohr-Coulomb } \\
\hline \multirow{3}{*}{ Strength parameters } & $\begin{array}{c}\text { Uniaxial compressive } \\
\text { strength } \\
\mathrm{R}_{\mathrm{c}}[\mathrm{kPa}]\end{array}$ & $\begin{array}{c}\text { Uniaxial tensile } \\
\text { strength } \\
\mathrm{R}_{\mathrm{t}}[\mathrm{kPa}]\end{array}$ & $\begin{array}{c}\text { Angle of shearing } \\
\text { resistance } \\
\phi '\left[{ }^{\circ}\right.\end{array}$ & $\begin{array}{c}\text { Cohesion } \\
\mathrm{c}^{\prime}[\mathrm{kPa}]\end{array}$ \\
\hline \multirow{3}{*}{ Material } & brick & 183.0 & 18.3 & - & - \\
\cline { 2 - 6 } & mortar & 130.0 & 13.0 & 45 & 20.5 \\
\cline { 2 - 6 } & ground & - & - & 35 & - \\
\hline
\end{tabular}

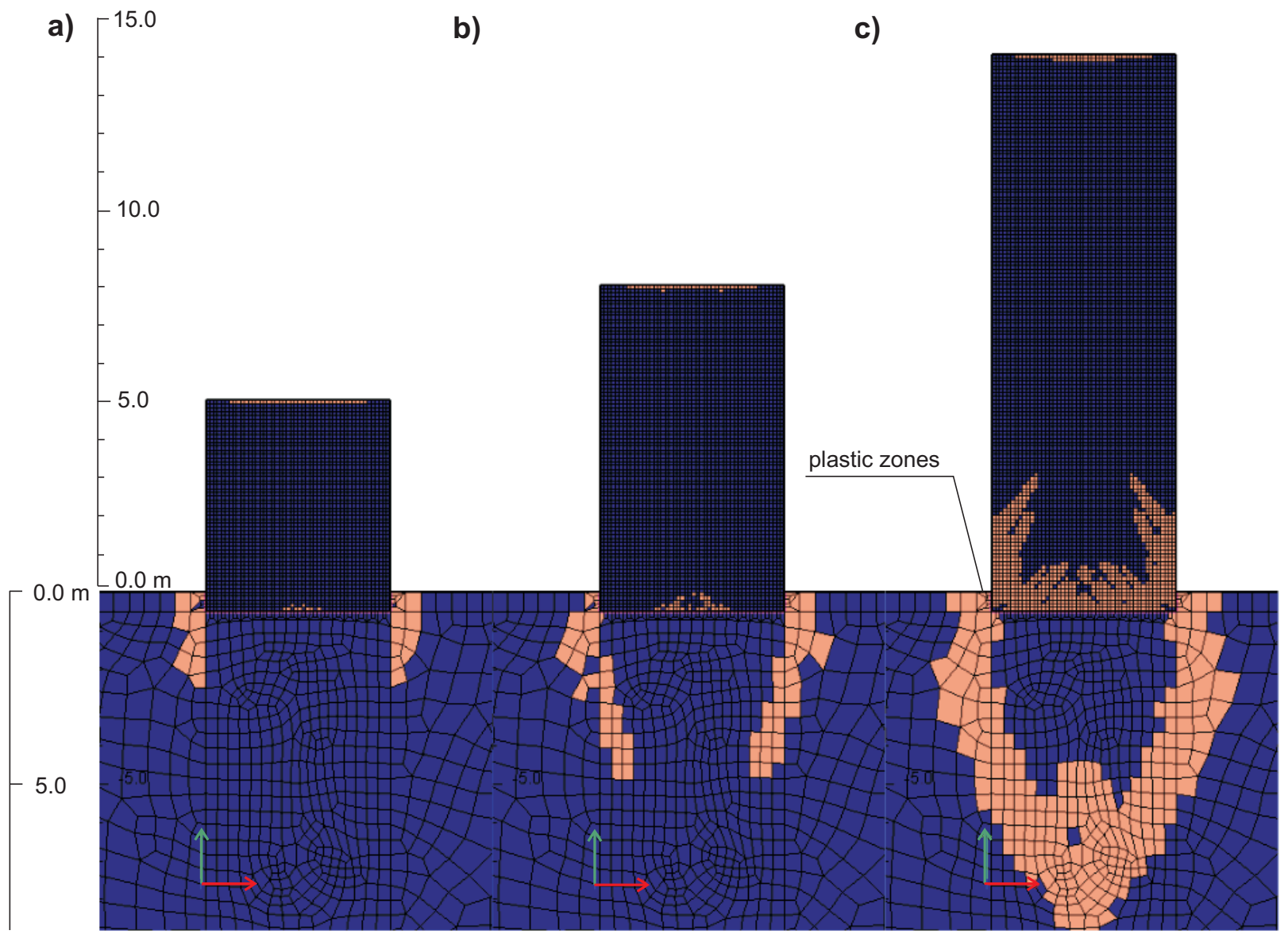

Fig. 4. Analysis of the height of a uniform wall in plain-strain conditions (2D). The subsequent stages of wall height increase are illustrated by models a), b) and c). Green and red arrows represent the vertical and horizontal axis of the model, respectively. Blue elements represent material zones exhibiting elastic behaviour at a given stage, while orange ones, those undergoing plastic flow, where the stresses exceeded the strength of the material. See text for detailed description. 




Fig. 5. Analysis of the height of a uniform wall in three-dimensional conditions (3D). Blue elements represent material zones exhibiting elastic behaviour at a given stage, while orange ones, those undergoing plastic flow, where the stresses exceeded the strength of the material. See text for detailed description.

possible height is $14 \mathrm{~m}$; at this height the ultimate limit state was exceeded, mainly in the ground, but also in the brick layers in the wall base. The plastic deformation zone in the ground was approx. $9 \mathrm{~m}$ deep for the maximal wall height, the brick layers exhibited plastic deformations to the level of $3 \mathrm{~m}$ at the external parts of the wall, and to the height of $1 \mathrm{~m}$ in its central part (Fig. 4c). At wall height not exceeding $8 \mathrm{~m}$, the plastic deformation zone in the bricks lying in the wall base is almost not existent in the central part, and ground deformations reach only to a depth of about $5 \mathrm{~m}$ (Fig. 4b). For a wall height not exceeding $5 \mathrm{~m}$, the substratum is deformed only to a depth of about 2-3 m (Fig. 4a).

A subsequent step in calculations was a modelling of the wall strength in a three-dimensional space (3D model). In this case, a wall was also used in calculations as a uniform structure (Fig. 5). The results obtained for this model are close to the results from the previous calculations for a flat two-dimensional state in the $2 \mathrm{D}$ model. The ultimate limit state was also exceeded at the wall height of $14 \mathrm{~m}$. In the 3D model, there are differences in particular plasticity zones. The deformation zone in a ground reaches down to a depth of $10 \mathrm{~m}$, and it is discontinuous and much narrower. In turn, a deformation zone in the wall base is clearer and wider in the marginal parts of the wall, and does not occur at all in the central part.

Further calculations attempted a more detailed wall representation and were linked with a subsequent element influencing the capacity of the analysed masonry structure. In this case, the brickwork was taken into account. One of the possible brick patterns in the wall was assumed (Spencer, 1979; Plate $15-\mathrm{AD}_{1}$ ), based on a scheme identified in other archaeological sites and at Tell el-Retaba (see Fig. 2 for axample of brick pattern at Tell el-Retaba). Brick sizes that occurred most commonly in fortification constructions at Tell el-Retaba, $40 \times 20 \times 10 \mathrm{~cm}$ (length $\times$ width $\times$ height), were assumed in the calculations. A grid of finite elements at mesh size $10 \times 10 \mathrm{~cm}$, analogous as in the calculations for previous models, was applied. Additionally, the joints 


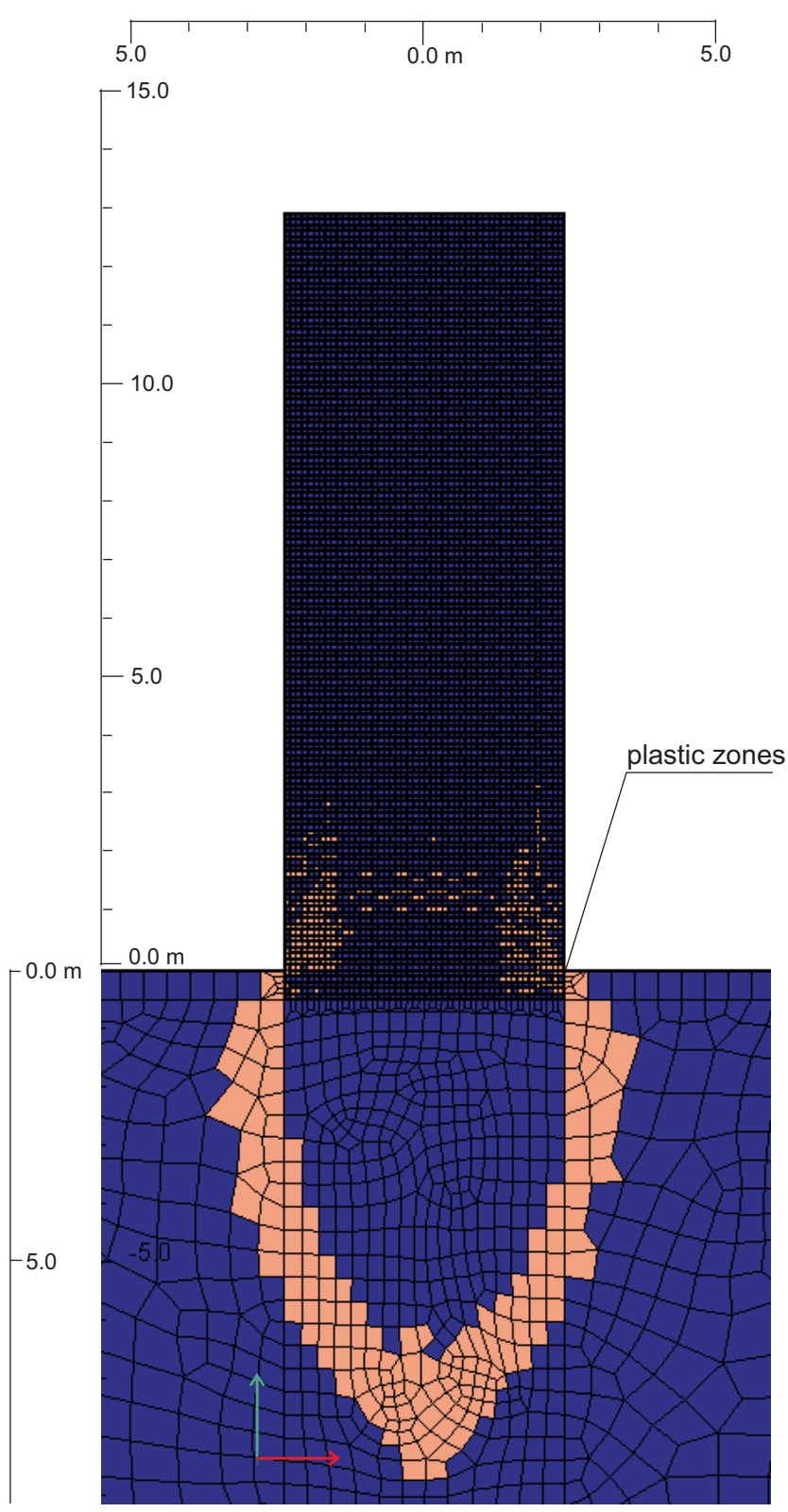

Fig. 6. Analysis of the height of a wall with brickwork and mortar in plain-strain conditions (2D). Green and red arrows represent the vertical and horizontal axis of the model, respectively. Blue elements represent material zones exhibiting elastic behaviour at a given stage, while orange ones, those undergoing plastic flow, where the stresses exceeded the strength of the material. See text for detailed description.

between the bricks were contact type interface elements, modelling the mortar. The ground conditions were the same as for the other models. The results of calculations for the plain-strain model (2D), including brickwork, have indicated that the structure lost its stability at the height of approx. 13 $\mathrm{m}$ (Fig. 6). This was also mainly due to a ground bearing capacity, in which the limit state was reached. The plasticity zones in the substratum reached to a depth of about $9 \mathrm{~m}$. The lowermost part of the wall at its base also underwent slight deformation, to a height of $3 \mathrm{~m}$ maximum. The largest deformations occurred for the external part of the wall to a height of about $1 \mathrm{~m}$, and in the central part - up to 1-2 $\mathrm{m}$.

\section{CONCLUSIONS FROM THE FEM ANALYSIS}

The following conclusions can be drawn from the calculations of the models:

- in the case of averaged parameters, and 2D and 3D models with a uniform wall, the substratum capacity is the main factor determining the boundary height of a wall (14 m);

- in a 3D model with a uniform wall, the boundary height was also $14 \mathrm{~m}$, whereas a destruction zone of the lowermost part of the wall became wider, which is the effect of a more detailed spatial analysis;

- in a 2D model of a wall with brickwork and mortar, the influence of brick jointing and mortar parameters are of low significance, and the maximum height of the wall in this case was approximately $13 \mathrm{~m}$.

It seems highly probable that larger variability between the 3D uniform model and the 3D model with brickwork and mortar may only be evidenced by three-dimensional calculations, in which a macro-scale strength of the construction accounting for brickwork will be included. Further works will aim at the analysis of spatial models with different brickwork and taking into account geometry and structure of particular walls from Tell el-Retaba without substratum (fixed boundary condition) and their support, including foundation conditions on a variable substratum to analyse different factors separately. The final effect of the works will consist of complex construction analyses reflecting particular wall types from the analysed archaeological site, taking into account the variable geometry of particular walls and wall elements, and their properties, as well as determining the ground bearing capacity.

\section{MODELLING OF A HEIGHT OF FORTIFICATIONS VS. ARCHAEOLOGICAL AND TEXTUAL SOURCES}

Data obtained during modelling should be compared with archaeological sources and texts confirming the height of fortifications raised by the ancient Egyptians. At Tell el-Retaba and at most other sites, the lowermost parts of the walls are preserved only. At some sites, however, the walls have been preserved to a considerable height, and in rare cases - also to original height.

The best preserved objects of fortification architecture are known from Nubia, from the times of the $12^{\text {th }}$ Dynasty $\left(19^{\text {th }}-18^{\text {th }}\right.$ century BC). The fortress system raised at that time was intended to protect the areas conquered by Egypt in the area between the $1^{\text {st }}$ and $2^{\text {nd }}$ cataracts (Vogel, 2004). It can be estimated that in the best preserved fortresses such as Buhen and Mirgissa, the maximum preserved wall height corresponds approximately to a half of its original height. At wall thickness reaching $8 \mathrm{~m}$, it is estimated that their original height was 10-14 m (Vogel, 2004: 120).

Unfortunately, such well-preserved fortresses from times of the constructions at Tell el-Retaba, i.e. the $19^{\text {th }}$ or $20^{\text {th }}$ Dynasties, were not preserved. However, sources from 


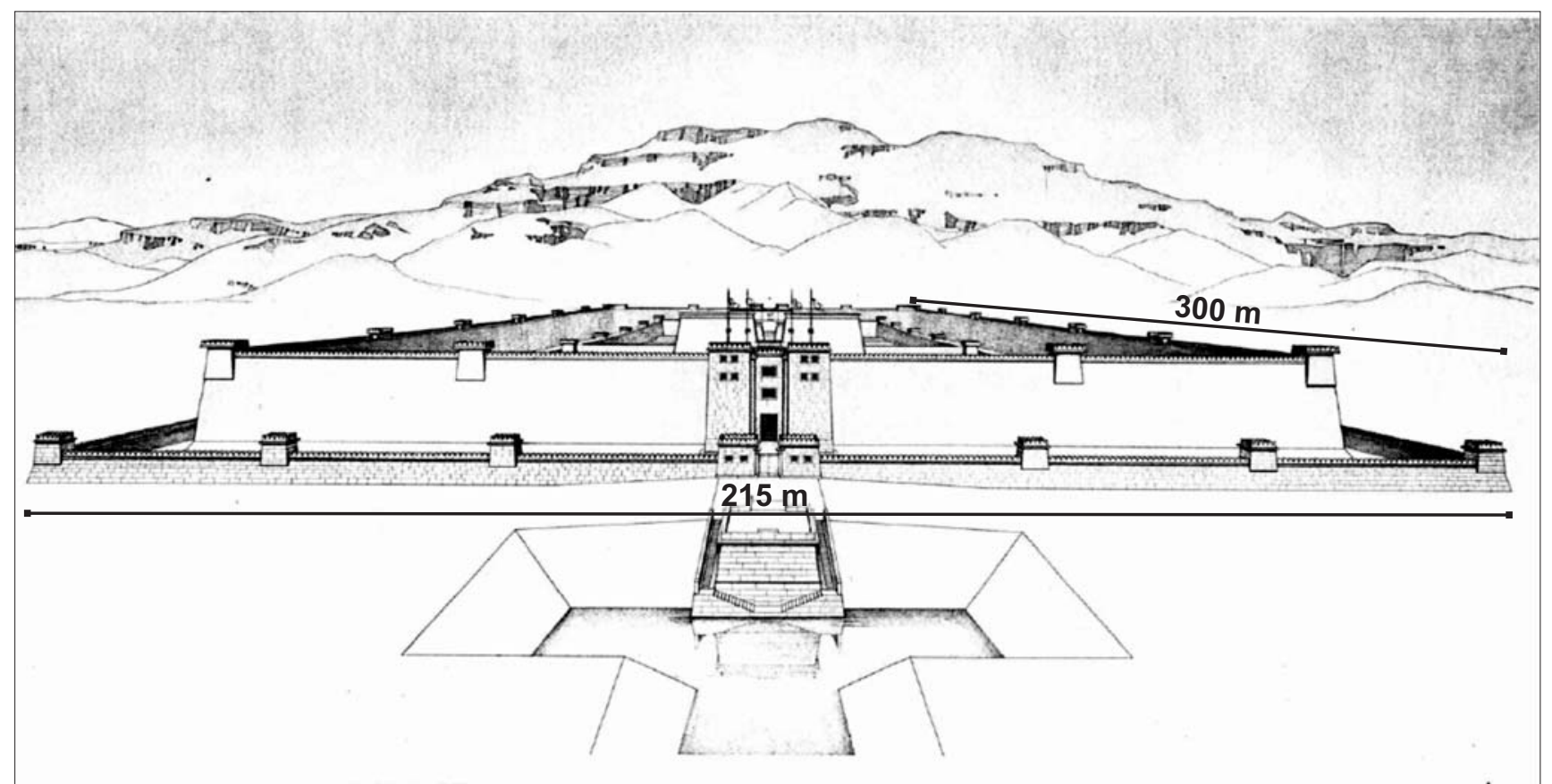

Fig. 7. Mortuary temple complex of Ramesses III in Medinet Habu - reconstruction drawing with the migdol in the centre. After Hölscher (1951): pl. 2.

that time allow for a very reliable estimation of the height of the fortress walls. The following paragraph can be found in the text of Papyrus Harris I (77: 6-8), which presents significant accomplishments of the reign of Ramesses III: "I made a very great $\underline{h} n m t$-well in the foreign land of Aiyn, which was enclosed with a wall like a mountain of sandstone consisting of twenty layers (of bricks) as a foundation (and reaching) a height of thirty cubits with the battlements, its portal doorjambs being of cedar, their bolts being of copper with mountings" (Morris, 2005: 719).

An Egyptian cubit is a unit of measurement with a length of $0.523 \mathrm{~m}$, therefore the fortified wall that Ramesses III ordered to be constructed around the well in Aiyn was $16 \mathrm{~m}$ high. Unfortunately, the text does not mention the wall width. The location of Aiyn remains unknown. It is quite possible that this could be the fortress of Kom elQulzoum near the Lake Timsah, at the eastern border of Wadi Tumilat. The fortress was surrounded by a $7 \mathrm{~m}$ wide wall, thus of a width comparable to the walls at Tell el-Retaba (Morris, 2005: 726, 742).

A reliable method of estimating the height of the walls of the Ramesses III's fortress at Tell el-Retaba may be done by comparison with the walls constructed for this ruler around his mortuary temple at Medinet Habu. Although this was a temple and not a fortress, solutions taken from fortification architecture have been applied there as well (Hölscher, 1951: 1-10). Entrance to the complex is through a migdol gateway, of similar shape and size as the migdol at Tell el-Retaba. The complex is surrounded by a mud brick wall, which was $10 \mathrm{~m}$ wide at its base (Figs 7, 8). The original height has not been preserved, but can be established with high precision. The migdol at Medinet Habu was built of stone and is completely preserved. Traces of walls built of mud bricks are preserved on its walls. The brick walls were 18.4 m high (Hölscher, 1951: 1).

\section{CONCLUSIONS}

Comparison of archaeological data from different sources shows that ancient builders, who used mud bricks as material that was easily accessible and produced upon site, must have had practical knowledge on the rules of constructing defence wall structures. There is a clear relation showing that a wider wall at the base resulted in a higher structure. This means that the final width of the wall depended on the planned height of the wall. Simple calculations made for examples of ancient constructions in Egypt and Nubia indicate that the height to width ratio was at the level of 1.75 to 1.85 , but never reached the value of 2 , i.e. double height to width. With high probability, slenderness at the level of 2 did not provide safety comfort and this ratio was probably not exceeded by the ancient constructors. A defensive structure must have had construction parameters providing a stable and safe appearance.

A second factor influencing the stability of such constructions was a strength of the material, in this case of mud bricks. Defence walls were among the most massive constructions that were built of mud bricks in ancient Egypt. As shown by various investigations (Trzciński et al., 2016), brick manufacturers must have been familiar with the basic technological rules of their production. They also knew how to improve the engineering properties of the material that is they knew from practical experience the basic rules 


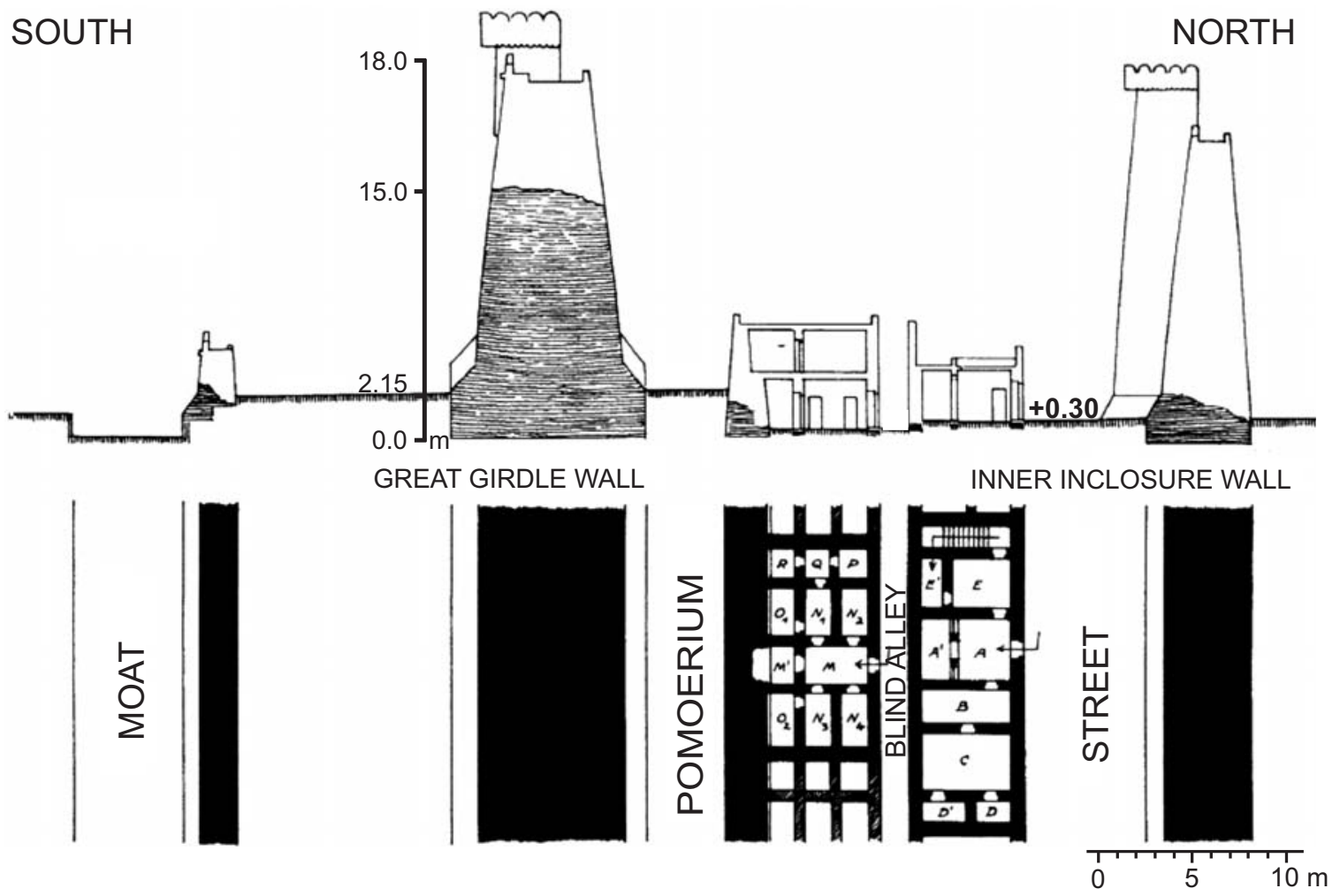

Fig. 8. Ground plan and cross-section of the enclosure wall and adjacent structures in the mortuary temple complex of Ramesses III in Medinet Habu. After Hölscher (1951): Fig. 15.

of selecting the components for their production. Most probably, they linked the strength parameters of the material with its later application, such as e.g. the size of the construction or its purpose.

A third element that the ancient Egyptians were aware of, were the ground conditions under the fortifications. It was supposed to hold the entire wall weight; thus, must have had a sufficient strength. The width of the wall to distribute the weight on a larger surface also had a significant role. Probably, the width to height ratio must have been known to the Egyptians and they linked it not only with the wall height but also with the bearing capacity of a ground. The assumed wall width must have depended not only on the substratum but also on the material, which in the lowermost part of the construction formed the widest layers and usually narrowed toward the top. The locality of the foundation must have been analysed prior to the decision on proceeding with the construction, which could also be linked with the preliminary preparation of the substratum for the wall construction (Trzciński et al., 2016).

As supported by the modelling results, unstable conditions occurred at the height of 13-14 $\mathrm{m}$ for an assumed wall width of $5 \mathrm{~m}$. The substratum was the main reason for instability, as its bearing capacity was exceeded. Additionally, at this wall height, the bricks from the lower part reached their maximum resistance. It should be assumed that such high walls were not constructed. At an assumed wall width of $5 \mathrm{~m}$ and the height to width ratio of 1.75 , the estimated wall height could reach about 8-9 $\mathrm{m}$.

\section{Acknowledgments}

The mission works under the auspices of the Polish Centre of Mediterranean Archaeology, University of Warsaw; involved are also: Institute of Archaeology, University of Warsaw, Slovak Academy of Sciences and Aigyptos Foundation, Bratislava. The works have been also supported by the Polish National Science Centre (Grant no. 2012/05/B/HS3/03748).

\section{REFERENCES}

Arnold, D., 2001. The Encyclopaedia of Ancient Egyptian Architecture, London - New York.

Emery, V.L., 2011. Mud-Brick Architecture. In: Wendrich, W. (Ed.), UCLA Encyclopaedia of Egyptology, Los Angeles.

Górka, K., Rzepka, S., 2011. Infant burials or infant sacrifices? New Discoveries from Tell el-Retaba. Mitteilungen des Deutschen Archäologischen Instituts Kairo 67, 93-100.

Hölscher, U., 1951. The Excavation of Medinet Habu, Volume IV. The Mortuary Temple of Ramses III, Part II, Chicago.

Kemp, B., 2009. Soil (including mud-brick architecture). In: Nicholson, P.T., Shaw I. (Eds), Ancient Egyptian materials and technology. Cambridge, 78-103.

Morris, E., 2005. The Architecture of Imperialism: Military Bases and the Evolution of Foreign Policy in Egypt's New Kingdom, Probleme der Ägyptologie 22, Leiden-Boston.

Petrie, W.M.F., Duncan, J.G., 1906. Hyksos and Israelite Cities. British School of Archaeology in Egypt 12, London.

PKN-CEN ISO/TS 17892-7 Geotechnical investigation and testing Laboratory testing of soil - Part 7: Unconfined compression test on fine-grained soils. PKN, Warszawa 2004. 
PN-81/B-03020. Building Soils. Foundation bases. Static calculation and design. Polski Komitet Normalizacji, Miar i Jakości.

PN-88/B-04481. Building soils. Laboratory test. Polski Komitet Normalizacji, Miar i Jakości.

PN-EN 1997-1:2008 Eurocode 7 - Geotechnical design - Part 1: General rules.

PN-EN 1997-2:2008 Eurocode 7 - Geotechnical design - Part 2: Ground investigation and testing.

Rzepka, S., Wodzińska, A., Hudec, J., Herbich, T., 2009. Tell el-Retaba 2007-2008. Ägypten \& Levante 19, 241-280.

Rzepka, S., Wodzińska, A., Malleson, C., Hudec, J., Jarmużek, Ł., Misiewicz, K., Małkowski, W., Bogacki, M., 2011. New Kingdom and the Third Intermediate Period in Tell el-Retaba. Results of the Polish-Slovak Archaeological Mission, Seasons 2009-2010. Ägypten \& Levante 21, 139-184.

Rzepka, S., Hudec, J., Wodzińska, A., Jarmużek, Ł., Hulková, L., Dubcová, V., Piorun, M., Šefč́áková, A., 2014. Tell el-Retaba from the Second Intermediate Period till the Late Period. Results of the Pol-
ish-Slovak Archaeological Mission, seasons 2011-2012. Ägypten \& Levante 24, 41-122.

Rzepka, S., Hudec, J., Jarmużek, Ł., Dubcová, V., Hulková, L., Odler, M., Wodzińska, A., Trzciński, J., Šefčáková, A., Sójka, P., Fulajtar, E., Černý, M., Tirpák, J., 2015. From Hyksos settlers to Ottoman pipe smokers. Tell el-Retaba 2014. Ägypten \& Levante 25, 97-166.

Sieczkowski, J., Nejman, T., 2002. Ustroje budowlane. Oficyna Politechniki Warszawskiej.

Spencer, A.J., 1979. Brick architecture in ancient Egypt, Warminster.

Truty, A., Zimmermann, T., Podleś, K., Obrzud, R., 2012. Theory ZSoil. PC 2012 manual. Elmepress International, Lausanne, Switzerland.

Trzciński, J., Zaremba, M., Rzepka, S., Welc, F., Szczepański, T., 2016. Preliminary report on engineering properties and environmental resistance of ancient mud bricks from Tell el-Retaba archaeological site in the Nile delta. Studia Quaternaria 33, 47-56.

Vogel, C., 2004. Ägyptische Festungen und Garnisonen bis zum Ende des Mittleren Reiches, HÄB 46, Hildesheim. 